\title{
Linear Growth Study of the Pharyngeal Cavity
}

\author{
WALTER A. CASTELLI, PERLA C. RAMIREZ, and CARLOS E. NASJLETI
}

Department of Anatomy and Center for Human Growth and Development, The University of Michigan and The Veterans Administration Hospital, Ann Arbor, Michigan 48104, USA

A cephalometric study was made to determine average linear dimensions and growth differentials of the pharyngeal cavity in boys and girls 6 to 15 years of age. The length of the cavity and its nasal openings had a faster rate of growth in boys than in girls, especially during puberty. Oral opening and laryngeal inlet did not vary between sexes.

Normal speech production, deglutition, and breathing are basic functional processes that are dependent, in part, on the patency and normal configuration of the pharyngeal cavity. Ricketts ${ }^{1}$ has stressed the importance of developmental abnormalities in the palatal region in the production of deep changes in voice and breathing patterns in human beings. Perez et $\mathrm{al}^{2}$ and $\mathrm{Dedo}^{3}$ also have reported on the morphologic changes that occur in the pharyngeal cavity because of pathologic or surgical interventions or both, and on problems when patients face rehabilitation procedures.

There is no doubt then that the pharyngeal cavity is a functionally important pathway that needs to be evaluated as such. Craniometric and other osteologic points have been used to assess pharyngeal areas primarily concerned with velopharyngeal physiology. In his study of the nasopharynx, King 4 found that the distance from the sellanasion to the posterior nasal spine was slightly greater in males than in females. Bergland $^{5}$ studied skull material from two different racial populations and found that the length of the dorsal border of the vomer was significantly greater in males. However, these studies were done on dried skulls without considering the soft tissues covering the bones. This last condition makes the previous data inadequate for determining the

Received for publication November I, 1972. true dimension of the pharygeal cavity. The necessity for the determination of average dimensional values of the pharyngeal cavity in normal individuals has been stressed by Wildman. ${ }^{6}$ He has emphasized the importance of pharyngeal soft tissues in velopharyngeal closure and speech, and has stated that skeletal variations cannot be considered direct criteria for determining pharyngeal functions.

The purpose of this research was to make a comparative study of linear growth of the pharyngeal cavity in boys and girls between 6 and 15 years of age by use of radiographic cephalometrics. The following variables were investigated: length of the pharyngeal cavity, nasal opening, oral opening, and laryngeal inlet.

\section{Materials and Methods}

Sixty standardized lateral view cephalograms from boys and girls aged 6 to 15 were selected randomly from the collection maintained in the Department of Orthodontics, School of Dentistry, The University of Michigan. The sample was separated by sex and grouped into the following age intervals: 6 $8.9,9-11.9$, and $12-15.9$ years. Midpoint values for each interval were 7.5, 10.5, and 14 years, respectively. The following sagittal dimensions were measured (Fig 1): (1) the length of the pharyngeal cavitya $A-B$, which is the distance from the most anterior and superior point of the pharyngeal roof $(A)$ to the posterior end of the aryepiglottic fold $(B)$; (2) the nasal opening of the pharyngeal cavity $A-C$, which is measured as the distance from point $A$ to the dorsum of the soft palate $(C)$ over the posterior nasal spine; (3) the oral opening of the pharyn-

- This portion of the pharyngeal cavity is always patent and functionally important for respiration and speech. 


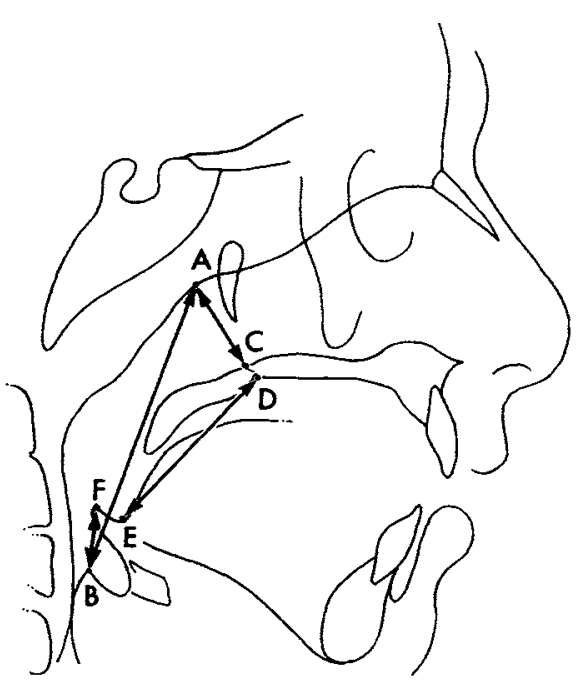

FIG 1.-Sagittal dimensions: $A-B$, pharyngeal cavity length; $A-C$, nasal opening; $D \cdot E$, oral opening; $F-B$, laryngeal inlet.

geal cavity $D \cdot E$, which is measured as the distance from the ventral surface of the soft palate $(D)$ over the posterior nasal spine to the median glossoepiglottic fold $(E)$; and (4) the laryngeal inlet $F-B$, which is the distance from the base of the epiglottis $(F)$ to the posterior end of the aryepiglottic fold $(B)$. Caliper measurements read to the nearest tenth of a millimeter were made by two investigators, and the values were averaged. To aid in the presentation of data and interpretation of results, $t$ tests were computed to determine the significance of the difference between means found for each linear dimension in boys and girls, in each of the three age groups.

\section{Results}

The results of our study are presented in the table and Figure 2. The length of the pharyngeal cavity in boys and girls increased during prepubertal years; this increase was not significantly different between the sexes. However, during pubertal years, a slightly significant increase occurred in boys $(P=0.05)$. Similarly, the height of the nasal opening was significantly greater in boys than in girls in all three age groups. In the first and second age groups $P=0.05$; in the third age group $P=0.01$.

The oral opening of the pharyngeal cavity

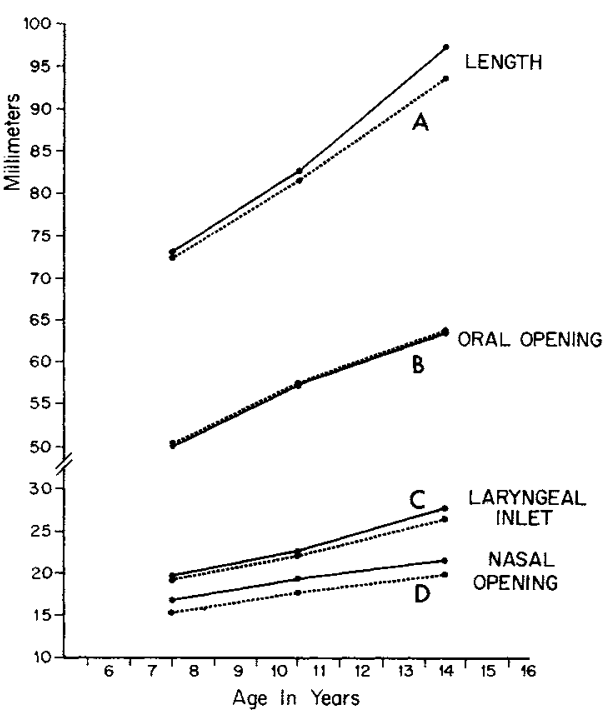

FIG 2.-Progressive linear growth changes in the pharyngeal cavity. Solid lines, boys; broken lines, girls.

and its laryngeal inlet did not show significant sex differences.

\section{Discussion}

The analysis of the data on the length of the pharyngeal cavity seems to support the results of a study ${ }^{7}$ on the volumetric capacity of the respiratory pathways. Seabury found that the anatomic dead space that extends from the nose through the bronchioles has a capacity of $150 \mathrm{ml}$ in adult males and only $100 \mathrm{ml}$ in females. Several authors have tried to explain the biologic processes involved in pharyngeal growth. Scott ${ }^{8}$ and King 4 have favored the hypothesis that pharyngeal growth is regulated indirectly by bone growth in the cervical vertebrae, interaticular cartilage, mandible, pterygoid processes, and hyoid bone.

Reifenstein ${ }^{9}$ has emphasized the influence of gonadal and adrenal cortical hormones on bone growth during pubertal years. This hormonal influence would be most decisive for feminizing and masculinizing alterations and for growth differentials between females and males. Moss and Salentijn, 10 on the ohter hand, have stressed the mechanical influence of breathing on the expansion and growth of the respiratory pathway. They have pointed out that the shape and size of the pathway, in general, is dependent on 
TABLE

Comparison of Progressive linear Growth of the Pharyngeal Gavity in 30 Boys and 30 Girls at Three Age Intervals

\begin{tabular}{|c|c|c|c|c|c|c|c|c|c|c|}
\hline \multirow[b]{2}{*}{$\begin{array}{c}\text { Linear } \\
\text { Dimensions }\end{array}$} & \multirow[b]{2}{*}{ Sex } & \multicolumn{3}{|c|}{7.5 years $(N=20)$} & \multicolumn{3}{|c|}{10.5 years $(\mathrm{N}=20)$} & \multicolumn{3}{|c|}{14.0 years $(\mathrm{N}=20)$} \\
\hline & & $\overline{\bar{x}}$ & SD & $t$ test & $\bar{x}$ & SD & $t$ test & $\bar{x}$ & SD & $t$ test \\
\hline $\begin{array}{l}\text { Length of } \\
\text { pharyngeal } \\
\text { cavity }\end{array}$ & $\begin{array}{l}\text { Male } \\
\text { Female }\end{array}$ & $\begin{array}{l}73.02 \\
72.44\end{array}$ & $\begin{array}{l}4.37 \\
4.17\end{array}$ & 0.53 & $\begin{array}{l}82.83 \\
81.75\end{array}$ & $\begin{array}{l}4.82 \\
4.21\end{array}$ & 0.93 & $\begin{array}{l}97.36 \\
93.84\end{array}$ & $\begin{array}{l}5.34 \\
5.09\end{array}$ & 2.62 \\
\hline $\begin{array}{l}\text { Nasal } \\
\text { opening }\end{array}$ & $\begin{array}{l}\text { Male } \\
\text { Female }\end{array}$ & $\begin{array}{l}16.97 \\
15.40\end{array}$ & $\begin{array}{l}2.51 \\
2.42\end{array}$ & 2.46 & $\begin{array}{l}19.39 \\
17.94\end{array}$ & $\begin{array}{l}2.37 \\
1.89\end{array}$ & 2.64 & $\begin{array}{l}21.60 \\
20.16\end{array}$ & $\begin{array}{l}2.31 \\
1.78\end{array}$ & 2.68 \\
\hline $\begin{array}{l}\text { Oral } \\
\quad \text { opening }\end{array}$ & $\begin{array}{l}\text { Male } \\
\text { Female }\end{array}$ & $\begin{array}{l}51.02 \\
51.28\end{array}$ & $\begin{array}{l}3.42 \\
2.91\end{array}$ & 0.31 & $\begin{array}{l}57.37 \\
57.51\end{array}$ & $\begin{array}{l}3.25 \\
3.34\end{array}$ & 0.16 & $\begin{array}{l}63.72 \\
64.77\end{array}$ & $\begin{array}{l}3.62 \\
3.76\end{array}$ & 0.68 \\
\hline $\begin{array}{l}\text { Laryngeal } \\
\text { inlet }\end{array}$ & $\begin{array}{l}\text { Male } \\
\text { Female }\end{array}$ & $\begin{array}{l}19.52 \\
19.33\end{array}$ & $\begin{array}{l}1.96 \\
2.10\end{array}$ & 0.36 & $\begin{array}{l}22.52 \\
22.40\end{array}$ & $\begin{array}{l}2.99 \\
2.24\end{array}$ & 0.17 & $\begin{array}{l}27.94 \\
26.79\end{array}$ & $\begin{array}{l}2.93 \\
2.17\end{array}$ & 1.72 \\
\hline
\end{tabular}

the functional volumetric demands involved in respiration. These opinions indicate that there is hormonal sex-linked control over bone growth during puberty which, along with breathing requirements and metabolic needs, probably is responsible for the sexual differences in the length of the pharyngeal cavity in boys and girls.

The same reasoning might explain the significantly greater height of the nasal opening in the pharyngeal cavity found in boys in the three age groups. The bony substrate of the nasal opening of the pharynx makes the morphologic condition of this region dependent on the overall process of growth and expansion of the nasal pathways and posterior upper face. Thus, the influence of breathing requirements, which started after birth and increased with greater metabolic needs, 7,10 and the genetic hormonal influence $^{9}$ during puberty, would control the expansive growth of the nasal pathway, and indirectly, account for the significant increase in the height of the nasal opening in boys.

The nonsignificant differences in the height of the oral opening in boys and girls probably indicated that the genetic hormonal influence during puberty is secondary in determining sex-linked diameters for this variable. Moss and Salentijn 10 have contended that functional metabolic demands should be considered primary determinant factors for shaping the oropharyngeal space. Probably, habits and food intake11 linked to biometric regulation imposed by the structures of the body, its cells and system, ${ }^{12}$ are determinant conditions involved in shaping the morphologic structure of a functional oral cavity.

The results of our study of the laryngeal inlet confirm previous findings; there was accelerated growth of the larynx in boys and girls during pubertal years. This acceleration has been attributed to a rapid anteroposterior growth of the laryngeal cartilaginous framework. ${ }^{13}$ Our data also indicates that growth was more pronounced in boys than in girls and that the difference may reach significant values during early adulthood.

\section{Conclusions}

The length of the pharyngeal cavity and its nasal openings had a significantly faster rate of growth in boys than in girls, especially during pubertal years. The oral opening of the cavity and the laryngeal inlet did not show significant sex differences when evaluated statistically.

The authors thank J. Harris, chairman, The University of Michigan, Department of Orthodontics, for the cephalograms used in this study.

\section{References}

I. Ricketrs, R.M.: The Cranial Base and Soft Structures in Cleft Palate, Speech and Breathing, Plast Reconstr Surg 14:47-60, 1954.

2. Perez, L.A.; Ogura, J.H.; Palmer, S.; BarnHILL, F.H.; and PoWERs, W.E.: Laryngography in the Selection of Patients for Conservation Surgery in Cancer of the Supraglottic Larynx and Pharynx, Am $J$ Roentgenol Radium Ther Nucl Med 103: 746-765, 1968.

3. DEDO, H.H.: Supraglotic Laryngectomy, In- 
dication and Techniques, Laryngoscope 78: 1183-1194, 1968.

4. KING, E.W.: A Roentgenographic Study of Pharyngeal Growth, Angle Orthod 22: 23-37. 1952.

5. Bergland, O.: The Bony Nasopharynx, a Roentgen-Craniometric Study, Acta Odontol Scand 21 (suppl 35), 1963.

6. Wrldman, A.J.: Analysis of Tongue, Soft Palate and Pharyngeal Wall Movement, $A m$ J Orthod 47: 439-461, 1961.

7. Seabury, J.H.: Pulmonary Ventilation and Respiration; Test of Respiratory Function in Sodeman, W.A. (ed) : Pathologic Physiology, Mechanisms of Disease, Philadelphia: W. B. Saunders Co., 1967, pp 505-534.

8. ScotT, J.: Craniofacial Regions.: A Contribution to the Study of Facial Growth, Dent Pract 7: 208-214, 1955.
9. Reifenstein, E.C.: Endocrine Glands in Sodeman, W.A. (ed) : Pathologic Physiology, Mechanisms of Disease, Philadelphia: W. B. Saunders Co., 1967, pp 136-189.

10. Moss, M.L., and SalentiJn, L.: The Primary Role of Functional Matrices in Facial Growth, Am J Orthod 55: 566-577, 1969.

11. Le Macnen, J.: Habits and Food Intake, in Cone, C.F. (ed) : Handbook of Physiology, Vol 1, section 6, Baltimore: Williams \& Wilkins Co., 1967, pp 11-30.

12. MAYER, J.: General Characteristics of the Regulation of Food Intake, in CoDE, C.F. (ed): Handbook of Physiology, Vol 1, section 6, Baltimore: Williams \& Wilkins Co., 1967 , pp 3-9.

13. ZemLin, W.R.: Speech and Hearing Science, Anatomy and Physiology, New Jersey: Prentice Hall, Inc., 1968, pp 212-213. 